University of Washington Tacoma

UW Tacoma Digital Commons

SIAS Faculty Publications

School of Interdisciplinary Arts and Sciences

$10-1-2015$

\title{
Starving for Diversity: Ideological Implications of Race Representations in the Hunger Games
}

Ellen E. Moore

University of Washington Tacoma, melle@uw.edu

Catherine Coleman

Follow this and additional works at: https://digitalcommons.tacoma.uw.edu/ias_pub

\section{Recommended Citation}

Moore, Ellen E. and Coleman, Catherine, "Starving for Diversity: Ideological Implications of Race Representations in the Hunger Games" (2015). SIAS Faculty Publications. 786.

https://digitalcommons.tacoma.uw.edu/ias_pub/786

This Article is brought to you for free and open access by the School of Interdisciplinary Arts and Sciences at UW Tacoma Digital Commons. It has been accepted for inclusion in SIAS Faculty Publications by an authorized administrator of UW Tacoma Digital Commons. 
Starving for Diversity: Ideological Implications of Race Representations in Hunger Games

Ellen E. Moore, University of Washington Tacoma

Catherine A. Coleman, Texas Christian University

Accepted to Journal of Popular Culture

\section{Introduction}

In March 2012, the film Hunger Games was released in U.S. theaters by independent film studio Lions Gate in the third largest film premiere in the U.S (Bowles). The film - about a young girl's life-or-death struggles - is based on a book series by author Suzanne Collins that, as of this writing, has held the number one spot in the "Children's Series" category on the New York Times' best seller list for two years. Aimed at young adults, the film drew in the same young, largely female audience who were fans of the Twilight film $\operatorname{series}^{1}$ (Bowles). Although the film was a box office hit, a controversy erupted when the movie hit theaters: many young Hunger Games fans who had read the book prior to seeing the film were shocked to find AfricanAmerican actors cast in some of the supporting roles. Fans seemed particularly upset with a Black actor playing the supporting character "Rue," and took to Twitter to express a range of emotions, including surprise, disappointment, and enmity.

The tweets are in sharp contrast to a society that increasingly tries to identify itself as "postracial," typically defined as moving away from evaluative considerations of skin tone and ethnic identity (Thornton 425). As such, they invite comment beyond the facile conclusion that this is an isolated occurrence fueled by a few uneducated individuals. To redefine the event as a result of more systemic issues, this research situates the Games' controversy within overlapping contexts that highlight the complex relationship between race and commercial media.

\footnotetext{
${ }^{1}$ Bowles provides a summary of Lions Gate's own findings: $80 \%$ of Twilight's moviegoers are women; women made up $61 \%$ of Hunger Games moviegoers.
} 
First, this article places the controversy within emerging discussions of the U.S. as a "postracial" society. Although polls have shown that the election of the first Black U.S. president has not changed racial attitudes significantly (Dowe), discussions of what it means to be postracial have been increasing in American news media, popular press, and academia (Wise; Kaplan; McElroy; Wenner). The importance of these conversations is underscored by the fact that almost all of the tweets came from young individuals (Anderson), throwing into doubt the belief that newer generations represent the vanguard of a "color blind" society. This research then examines representations of race in Hunger Games in the context of media production, focusing especially on the profit-driven nature of U.S. media corporations. In concert with an understanding of the Games controversy, the two avenues of inquiry address how the culture industry contributes to beliefs about race in a "postracial" society. Mediated representations have ideological implications (Hall, “The Whites" 89), and the fans' tweets provide an effective lens through which to study those connections.

\section{The Hunger Games Controversy: Fans' Reaction to Race Representations}

In both book and film format, Hunger Games is a multilayered critique of power and conflict. On a manifest level, the story is about a girl who fights with 23 other young people in a televised battle to the death, mandated by her government as a way to control a formerly revolutionary populace. Like most media texts, however, Hunger Games contains deeper connotations, including criticisms of the Iraq War (Valby) and the hegemony of totalitarian governments that crush powerless citizens, especially those with few or no resources.

Significantly, Hunger Games also is critical of the American media industry in two interrelated ways. First, it questions the pervasiveness of social media, where American youth grow up in an intensely mediated culture, one where they feel their every move is watched (and judged) in a 
way that echoes the Foucauldian concepts of panopticism and surveillance. Second, Hunger Games criticizes a society that uses mediated glimpses into individuals' private lives ("reality TV") as a form of entertainment or "sport" that turns injury and humiliation into commodities ${ }^{2}$. Considered as a whole, the film contains complex commentaries about commercial and political power that center on inequalities of age and class. Young fans' responses to African American representation in the film, however, prompts the question of whether there is an additional level of signification in the film: that is, does Hunger Games also contain messages about race?

In an interview before the film was released, Collins noted the "futuristic" setting for her book: the United States is gone and replaced with the country of "Panem" thousands of years in the future (Valby). The significance of this jump in time is that the characters live in what Collins refers to as a "multi-racial culture" with a considerable amount of "ethnic mixing." Even with the explicit description of broad racial admixture and the dark skin and eyes of select characters, some fans who had read the book were shocked to find African-Americans cast in the film, most notably "Cinna" (played by Lenny Kravitz), "Thresh," (Dayo Okeniyi), and "Rue" (Amandla Sandberg). Fans were particularly upset with Rue, and expressed their anger in hundreds of "vulgar racial remarks" (Holmes) $)^{3}$ :

"I was pumped about the Hunger Games. Until I learned that a Black Girl was playing Rue." "why does rue have to be black not gonna lie kinda ruined the movie" "And, for the record, im still pissed that rue is black. Like you think she might have mentioned that...?"

"I know, rue is too black for what I pictured. But Peeta IS nomworthy" "some ugly little girl with nappy [ass] hair. Pissed me off."

\footnotetext{
${ }^{2}$ For more on the commodification of humiliation in commercial television, see Mendible.

${ }^{3}$ As collected by the anonymous tumblr Hunger Games Tweets: http://hungergamestweets.tumblr.com
} 
"HOW IN THE WORLD ARE THEY GOING TO MAKE RUE A FREAKIN BLACK BITCH IN

THE MOVIE?!?!?!?!??! Lolol not to be racist buuuuuuut... I'm angry now

"EWW rue is black?? I'm not watching"

"Sense when has rue been a nigger"

"Kk call me racist but when I found out rue was black her death wasn't as sad."

These and other tweets caught the attention of a anonymous man who calls himself "Adam" in interviews who began to collect the tweets on tumblr. The tweeters were identified through photos and names associated with their accounts, revealing that most were teens (Holmes).

Reaction to the tweets on the Internet was harsh, and partially encouraged by "Adam" as a way to publicly shame the tweeters. The controversy attracted the attention of Dodai Stewart on the blog Jezebel, who criticized the teens on her website. Stewart noted that most of the individuals identified on the tumblr site had removed their accounts or made them private due to harassment or embarrassment. Meanwhile, L.V. Anderson at Slate contacted some of the tweeters and met with resistance from them and other teens who defended them.

Holmes notes that the tumblr site provides "a potent mix of pop-culture criticism, socialmedia sharing, provocative statements, and public shaming." One mystery surrounding the case is why fans reacted so negatively to the Black characters, as it is a common recognition that "the silver screen has long remained a white screen" (van Ginneken 225). Hunger Games follows the same pattern: the central characters are White while people of color are limited to supporting roles. The question then becomes: If this film followed the usual trends in casting, what sparked the outburst by young fans? The tweets provide a momentary glimpse into how young individuals immersed in U.S. media culture think about race, presenting a valuable case study to examine the complex interrelationship of commercial media and perceptions of difference in a 
society that publicly strives to free itself from a historical lineage of racial inequality.

\section{Reading Hunger Games: Interpretive Frameworks}

To interpret the racial controversy surrounding the Hunger Games, this research conducts a 'symptomatic reading' on the Hunger Games as defined by Althusser and Balibar:

All that a simple literal reading sees in the arguments is the continuity of the text. A 'symptomatic' reading is necessary to make these lacunae perceptible, and to identify behind the spoken words the discourse of the silence (86).

The idea that silence conveys significant meaning has precedent in scholarship focusing on race and the media, including Entman and Rojecki's observation that "the media's influence encompasses relevant info they fail to convey as well as material they pass on" (42, emphasis added) and the contention of Van Dijk (in Abraham) that racism often is "expressed by the unsaid" (90). This research thus uses symptomatic reading as an interpretive method to understand Hunger Games on two basic levels: assessing race representations in the film but also evaluating the "silences" about race that become apparent.

Conducting a symptomatic reading is intended to elucidate the problematic, namely, the beliefs and assumptions that underpin a text:

Every imaginary (ideological) posing of a problem... carries in it a determinate problematic, which defines both the possibility and the form of the posing of this problem. This problematic recurs as its mirror-image in the solution given to this problem by virtue of the mirror action peculiar to the ideological imagination (Althusser and Balibar 116).

The problematic recognizes the potential of a text to reflexively answer a perceived question (whether or not it has actually been posed) in advance and, in so doing, provide a solution to an $a$ 
priori problem. It is closely connected to ideology, because "all narratives contain an ideological project: that is, they promise to tell the truth about something" (Storey 78). Althusser writes that ideology "represents the imaginary relationship of individuals to their real conditions of existence," and thus represents an illusion of - via an allusion to - reality (304). For Althusser, one of the defining characteristics of ideology is that it exists primarily as a relationship between the producer of a text and the audience, a point recognized by Barthes in his assessment of the "double function" of ideology: "it points out and it notifies, it makes us understand something and it imposes it on us" (297). The notion that ideology requires both text and subject coheres with the goal of this research to make explicit how a commercial film like Hunger Games "hails" its young audience - in other words how they are identified and positioned by the Hollywood culture industry as subjects - to better understand fans' reaction to race representations. Here, Hunger Games, a Hollywood "tent pole" production, is positioned as a commodity form, defined by Marcuse as the "common denominator" to which the products of the commercial culture industry can be reduced (57). As a result, the film and the controversy that surrounds it are considered to be representative of broader patterns in the U.S. culture industry.

As part of a symptomatic reading to deconstruct the problematic within Hunger Games, representations of race are considered in three key ways: Inclusion, Roles, and Control. Croteau and Hoynes provide a detailed description of each:

Inclusion: Do media producers include different racial or ethnic groups?

Media Roles: If different racial or ethnic groups are included, what roles are they given—ones that represent diversity or stereotypes?

Control of Production: What is the role of producers and media owners in how race or ethnicity is presented? How does media ownership impact portrayals? (190-191). 
Analyzing representations of race in the films according to these criteria provides one approach to understanding racial ideology within the context of an Althusserian problematic: evaluating inclusion of actors of color in the film closely relates to a symptomatic reading on "silences" within a text, or what Storey refers to as a "double reading" (74); consideration of roles provides a way to access what Hall refers to as the "politics of representation" ("The Spectacle" 277) regarding portrayals of race in the film; and an assessment of control (in terms of media production and ownership) is useful to understand how producers of Hunger Games attempt to position their audience in terms of racial subjectivity, acknowledging Kellner's call to contextualize critical analyses within political economy (41). Attention to media production also answers questions about the motivation for race representations: Hall notes that ideologies are seen to “"work' by constructing (individual and collective) positions of identification and knowledge that allow them to 'utter' ideological truths as if they were authentic authors" ("The Whites" 90). Since motivation is necessary to myth (Barthes 126), this research intends to reveal what myths about race are presented as natural to the youthful fans of the Hunger Games.

\section{Previous scholarship on African American representation in mainstream media}

Numerous studies have revealed a commercial media system that for years has failed in many ways to represent minorities adequately, proportionately and diversely (e.g., Sanders and Ramasubramanian; Mastro and Greenberg). Throughout the $20^{\text {th }}$ century, African Americans were represented in limited roles that often reflected racial history more than signs of social and political progress, including: early slave imagery replicated in "nostalgic" advertising images (Aunt Jemima); the adaptation of minstrel show conventions from stage to radio and television (Amos n' Andy); cinematic representations (King Kong, the Blaxploitation films of the 1970s); and prime time television sitcoms (Isaksen 751; Kern-Foxworth; Gabriel; Coleman). Criticisms 
of contemporary representations of race reveal that little of substance has changed, as people of color continue to be stereotyped, marginalized, commodified (Henderson; Ladson-Billings; Kern-Foxworth;), or simply excluded (e.g., Goslet; Dubrofsky 40).

While progress is evident in both the inclusion and visibility of African Americans (e.g., Karate Kid, 2009; I Am Legend, 2008; Red Tails, 2012; and Think Like a Man, 2012), much of that progress is superficial while deeper examinations reveal underlying problems about the quality of those representations (de Oca; Abraham 90; Sanders and Ramasubramanian; Henderson 1207-1210). Examples include King Kong (2005), the repackaging of Marion Cooper's (1933) thinly-veiled reference to the Black male body as powerful, primitive, and dangerous (Snead 8); The Blind Side (2009), a film purporting to tell a story about Black NFL star Michael Oher's success from abject poverty to NFL stardom but in reality frames his story within a "romantic, white savior narrative that takes place on a postmodern plantation" (de Oca 132) ${ }^{4}$; and The Help (2011), a film about racism experienced by Blacks in the Deep South that did not rely on the compelling performances of Black actors to carry the movie, but instead used a White actor as the lead (Goodykoontz). These examples demonstrate a clear pattern in Hollywood's representation of Blackness: it either is marginalized, excluded, used to define Whiteness, or marked as different (Snead 4).

The pattern of negative race representations is not limited to Hollywood film. A recent study revealed that, out of 5,000 children's books published in the U.S. in 2011, less than $1 \%$ are by or about African Americans (CCBC). In commercial news, African Americans are overrepresented as criminal offenders and welfare recipients at levels disproportionate to crime and welfare data, despite the fact that Blacks are more likely to be victimized (Entman and Rojecki 67; Corley 48,

\footnotetext{
${ }^{4}$ The Blind Side also presents Oher as owing even his football ability to the White woman, who is shown explaining the game to him in a way that fundamentally shapes his sports' skills.
} 


\section{1; Dixon 152; Gilliam et al.; Weiss and Chermack).}

The consistently negative portrayals of African Americans in media invite contextualization within a political economy framework, as shifts toward increasingly profit-driven, concentrated media companies drown out alternate, diverse voices (McChesney). In the commercial culture industry, because film studios "have become embedded within much broader corporate frameworks," only few (Eurocentric) voices dominate (van Ginneken 8). According to Bernardi ("Introduction" xv), the institutionally-created "color line defined by Whiteness [has] directed the trajectory of the Hollywood style." In the context of a profit-driven media landscape, Blackness often is reduced to a narrowly-defined commodity presented as either dangerous or irrelevant for mainstream audiences. This pattern is not accidental: as Bernardi notes, commercial media "has consistently constructed whiteness, the representational and narrative form of Eurocentrism, as the norm by which all 'Others' fail by comparison" ("The Birth” 5). What is puzzling about these detrimental representations is the rise of public discussions about the development of a "postracial" American society, one where color lines are supposed to have disappeared.

The election of President Obama brought the civil-rights era version of a postracial society to the broader attention of the American public (Byrne; Romano, Ammah-Tagoe and No 43). Numerous scholars have described the concept of a postracial society in different ways. Wise describes it as a "rhetoric of racial transcendence" and "colorblind public policy" used in the election campaign of Barack Obama, with its origins in the civil rights revolution (16) to benefit people of color by prohibiting inequity based on skin tone or ethnic affiliation. However, discourses of "postracialism" have been used by neo-conservatives in the 1990s to defeat affirmative action. As Okamura argues, postracialism can be thought of in two ways: to not 
discriminate against others because of the color of their skin, and to not help people of color because the "significance of race" is supposed to be denied (p. 134). The concept is unstable in the sense that the belief that skin color shouldn't matter feeds the paradoxical belief that ethnicity doesn't serve as a structural barrier (Okamura 134). As de Oca observes, "postracial discourse constructs the United States as having moved beyond racial discrimination, especially since the election of Obama. There, contemporary racial inequities stem from minorities' own poor choices and any reference to race or racism is itself considered racist" (135).

The postracial concept is connected with the Althusserian problematic, as the numerous conversations in popular press about the emergence of a postracial society seem to answer the $a$ priori question of whether racism remains a problem in the U.S. The commercial media industry too seems to have the same answer by increasing inclusion of characters of color on the screen. As a result, Blackness becomes controlled, contextual and flexible sets of representations that reinforce the postracial ideology, while at the same time being managed by persistent structurally-bound ideologies "informed and fortified by whiteness" (Joseph 249). Henderson argues that despite what some have considered a post-9/11 "enlightened consciousness of the academy" (1208) that includes the adoration of a few black stars and athletes for their accomplishments, a truer assessment is that mainstream media persist in keeping black characters in roles that simply recast old stereotypes, or alternatively in "whitewashing" media representations.

According to Gabriel, “"Whitewash' refers to the process of cultural bleaching... The media [play] a key role in buttressing whiteness with selective versions of national culture by mobilizing deep-seated anxieties and insecurities whilst simultaneously seeking to counter such anxieties with discourses which serve to purge culture of its syncretic forms" $(4-5,9)$. 
Whitewashing can take many forms, including the casting of White actors in roles meant for people of color (Stewart); the erasure of people of color, as when Universal Pictures removed a Black couple from its Couples Retreat movie poster entirely in marketing to overseas audiences (Goslett); or literal washing, when a 2011 Dove soap ad equated Blackness with uncleanliness ${ }^{5}$.

The review of literature indicates that while U.S. society engages in serious public discussions about what it means to be postracial, myriad forms of historically embedded racism marginalization, exclusion, stereotyping - persist in commercial media. Representations of race are created within highly structured systems of power that ultimately provide the ideological foundation for media products. Examining how a contemporary media text like Hunger Games represents people of color to a young audience thus provides a key route to understand the relationship between commercial media, representation, and the continuance of racial "myth."

\section{Representations of Race in "Panem": Analysis}

Interpretation of Hunger Games begins at the level of inclusion. There is some diversity in the film, as several supporting roles are filled by African Americans. What is interesting is that the diversity ends there: there are no other ethnic groups included except a few unnamed extras. In terms of the presence or absence of people of color, Hunger Games closely parallels the commercial film industry. A list of the top-grossing films of 2010 and $2011^{6}$ - including films from the Harry Potter, Iron Man, and Twilight franchises - reveals that the vast majority (18 out of 20) of the films feature White actors in lead roles while characters of color fill auxiliary roles. The finding that familiar patterns of Whiteness dominate the Hunger Games should be unsurprising for serious students of the commercial media industry. As Entman and Rojecki (57)

\footnotetext{
${ }^{5}$ From Dove's "VisibleCare" bodywash ad released in May, 2011

${ }^{6}$ List of 2010 top grossing films from Huffington Post (http://www.huffingtonpost.com/2010/12/31/the-top-10grossing-films-of-2010_n_802483.html\#s216852\&title=Clash_of_the); List of 2011 top grossing films from USA Today College (http://www.usatodayeducate.com/staging/index.php/2011-year-in-movies)
} 
reveal, "Media images still contain traces of long-standing cultural presumptions not only of essential race difference but of the hierarchy that idealizes 'Whiteness."'

The next level of inquiry - the types of roles given to the characters - reveals more complexity. Cinna, Katniss' stylist in the film, is identified as moral, intelligent, and trustworthy. In many ways he is presented more favorably than the White citizens of the Capitol, as he avoids the typical overindulgences of food and dress and shuns the violent entertainment of the "Games." Sober and unassuming, he appears akin to an older brother or father figure who supports Katniss throughout the film. Significantly, Cinna is never "marked" as an "Other"; that is to say, his ethnicity is never used as a defining element of his character. This is important because any call to attention of an individual's ethnicity in the media, even if positive, serves to mark a person as different, or "Other" (Entman and Rojecki 57).

Rue is the character at the center of the tweeting controversy, as her portrayal is what seemed to anger some fans the most. Diminutive and intelligent, the character displays a keen grasp of strategy, including when she suggests to Katniss that she release a wasps' nest into the competitors' camp. She also displays kindness by healing Katniss' wasp stings even though her death would have gotten Rue closer to victory. Ultimately, she dies as the result of a spear thrown into her chest. The outrage and sadness audiences are supposed to feel over Rue's death is reinforced by Katniss, who mourns her by creating an elaborate flower memorial. Rue provides a martyr figure around which the audience (like the poor populations in the film) can feel outrage towards those who control the Games. Although her dark skin and eyes are described in the book, Rue's ethnicity - like Cinna's - does not define her character: she is presented simply as a girl too young and kind to be able to survive the Games. Her identity, 
however, changes significantly with the addition of Thresh.

“Thresh,” played by Nigerian-born actor Okeniyi, diverges significantly from Cinna and Rue: where they are steady and kind, Thresh is dangerous and unknowable. The book's description of him - "sullen and hostile," "a silent, deadly power," "one of the giants, probably six and a half feet tall and built like an ox" - conforms to the animalistic, physically imposing Brute archetype for African Americans identified by Bogle (13-14). Identification of Thresh as a wild animal is reinforced when he conceals himself in tall grasses during the Games, attacking and killing others who enter his territory. In addition, unlike the other White male "tributes" forced to participate in the "Games," he does not partner with others but instead isolates himself.

Thresh is different from Rue and Cinna in that his body as an "African-Panemian" has been "assigned social meaning" to be marked as an "Other" (Jackson, 12). Ultimately, it is the portrayal of his relationship with Rue that serves to define her in the same vein - as different due to the color of her skin. After Rue's death, Thresh encounters Katniss and refrains from killing her. His explanation: Katniss cared for Rue, and thus she is spared - one time. His counterintuitive behavior should be explained, since if he killed her he would be one step closer to surviving. The reason appears to be that Rue and Thresh come from the same majority Black district, the only one in overwhelmingly White Panem. Thresh and Rue are thus marked in the text as "Other" - they have their own distinct allegiance that is seemingly based on racial affiliation. In addition, the official Hunger Games' map $^{7}$ places their fictional district in the area of Mississippi, Alabama, and Louisiana - states that have a high proportion of Blacks relative to the rest of the U.S. ${ }^{8}$ If Collins was attempting a critique of racial discrimination and segregation in the U.S. it is a weak argument: Rue and Thresh's racial difference becomes highlighted,

\footnotetext{
${ }^{7}$ Available from the Universal Pictures' "Hunger Games Adventure" App

${ }^{8}$ Cited from 2010 U.S. census.
} 
segregating them on the screen and inviting perception of these characters as markedly different than the White tributes, while providing no clear reason for it. As a result, Rue and Thresh become part of the representational pattern Snead observes, where the color black is "marked redundantly... to force the viewer to recognize the image's difference from white images" (5).

An evaluation of the roles played by Black characters in the Hunger Games is complemented by Croteau and Hoynes' third category of analysis: control. To make the latent assumptions about race manifest, this research examines the crucial shift in race representation that took place when the book was converted to the film. The conversion to a commercial Hollywood product thus represents an important juncture in the tweeting controversy.

Noted earlier, the characters in Collins' book live at an unspecified time in the future and, as a result, represent a broad racial admixture. Although several characters in the book are clearly either Black or White, the main character and her potential love interest are racially ambiguous, with "olive skin," "black hair," and "grey eyes." Thus, the book suggests characters that are not White but instead could resemble Native Americans, Latinos, South Asians, and Arabs, among others. But actors of color never filled these central roles; instead, blonde, pale, blue-eyed Jennifer Lawrence was chosen for the role of Katniss, a move that was controversial since some readers perceived a more multi-racial individual (Alexander). In an interview, Collins and Lions Gate director Gary Ross responded to criticisms about "whitewashing” the lead characters by contending that they simply chose the best actors regardless of race (Valby). However, the Wall Street Journal published the casting call for the film: "She should be Caucasian, between ages 15 and 20, who could portray someone "underfed but strong," and "naturally pretty underneath her tomboyishness" (Jurgensen). Thus, a Native American, African American, or any non-White had no chance to audition for the lead roles, contrary to what Collins and Roth claimed. The 
organization Racebending criticized the casting as reflecting "the continued barriers actors of color and communities of color face in accessing representation in film" (Jurgensen).

In casting White actors as leads, Collins and Ross adhere to typical patterns in Hollywood, and in particular for films made for teen and young adult audiences, including the Twilight series that contained some diversity in race representation: one African-American, a Latina, an Asian, and several Native Americans. However, the three central characters in Twilight (including one who plays a Native American) are White. Hunger Games and Twilight thus fall into the familiar pattern that Dubrofsky recognizes that in commercial media, marginalized people of color often "work only to frame the narrative about white people" (40).

In an analysis of control, it is worth asking why the racial ambiguity in Collins' book which avoided tokenism and Eurocentrism - changed in the conversion to the screen. The answer comes from media producer George Lucas. In an interview with Jon Stewart on the Daily Show a month before Hunger Games was released, Lucas noted the difficulty of producing his World War II film Red Tails about the African-American Tuskegee Airmen. Observing that the film took 23 years to make, Lucas revealed that none of the Hollywood studios would take a film with an all-Black lead cast because they believed it would impact their profit margins. The fact that the film was "too Black" translated directly into not being "green" enough for the studios, with Lucas referring to box office sales.

The pattern of major media producers marginalizing or simply excluding non-Whites is easily explained when profit is the bottom line for major film studios. McChesney suggests, "in the last thirty years there's really been an institutional shift that's integrated movie making into the much broader industries of marketing, advertising and selling products." If Collins envisioned a broad spectrum of color when she wrote her book, it was the conversion to 
commercial film that fundamentally altered the more egalitarian representations of race by creating Black and White binaries that did not exist in the book. The apparent perception by Lions Gate that having lead characters of color would sink box office sales presses the question of why people of color were included in the film at all. hooks provides one reason: that "one desires a bit of the 'Other' to enhance the blank landscape of whiteness" (185). However, in a society still characterized by racial divisiveness and conflict, there may be a more compelling reason for the Games' limited inclusion of people of color.

In an analysis of the television show Psych, Thornton indicates that the presence of African Americans serves a key purpose for media producers: to reassure viewers of a true shift to a postracial society, both on and off screen, by adapting an assimilationist text "to rhetorically intensify post-race ideology" and to reassure "audiences of their distance from racism" (424). Thornton clearly identifies the problematic in Psych: it addresses concerns about racism in a society increasingly focused on re-defining itself as free from structural and personal racism. From this perspective, African Americans are included only for the purpose of being able to ignore them, or simply to limit conversations about racism (Thornton). In the Twilight series, characters of color are so secondary to the story that they can easily be ignored. Young audiences who watch Twilight are thus reassured that diversity is present, yet are not called to develop a relationship with the characters, instantiating Abraham's observation that most Hollywood films include people of color only to assuage uneasy White audiences.

Understanding commercial media production is key to identify the Althusserian problematic for this research, as it is here that one can identify clear choices by Lions Gate regarding inclusions and omissions in Hunger Games that are based on political economy considerations. Analysis reveals that the answer provided by Hunger Games to the perceived question or 
"problem" about race is two-pronged: 1) How to generate the highest profit; and 2) How to address persistent criticisms of racial exclusion and marginalization in the industry. The first explains why White actors were placed in lead roles in the film, while the second explains why actors of color were included in supporting roles. That is, if Hunger Games addresses questions about racial equality through inclusion of diversity on-screen, then discussions about racism in the U.S. - including in culture industries - should become irrelevant according to the logic of the problematic.

Given the supposedly satisfactory answer to diversity, the producers of Hunger Games likely were surprised both by criticisms of too much Whiteness in the film and also by racist tweets critical of the presence of Black actors. After all, it seemed they followed "normal" patterns of race representations in Hollywood. But had they? The difficulty that some young fans had regarding Rue's identity in the film appears to center on their imagined impression of her when they read the book. As analyses have indicated (Anderson; Holmes; Stewart), when these fans read the book they did not picture Rue as Black, despite the clear description in the book; instead their "default" ethnicity was White. Holmes observes "the white default" - the inclination by media consumers to imagine Whiteness in not only the Hunger Games' characters but in other forms of mass media - "is learned and internalized early." "The Hunger Games case speaks volumes about Whiteness as a default, or "neutral", identity, a trend noted elsewhere (Gabriel 2).

It is here that we can begin to articulate the Hunger Games as an ideological text with the audience as subject. The film's portrayal of Rue invited compassion. Although an ancillary character whose presence serves to further the story of the White lead character, Rue is

\footnotetext{
${ }^{9} \mathrm{~A}$ recent example of this is the Canadian Bank altering a drawing of a female Chinese Canadian scientist on the new $\$ 100$ dollar note because focus groups thought it favored one ethnic group over another (Beeby). The image of the Chinese woman on the bill was replaced with a "neutral ethnicity" - White.
} 
inherently likable. Discussed in the book as reminding Katniss of her younger sister, audiences are encouraged to feel protective of Rue, the youngest tribute in the Games. Ultimately, when she dies and Katniss mourns, Rue's innocence and worth as a human being is underscored.

Young fans who read the book responded to this appeal by making an emotional connection with Rue. The problem for Lions Gate was that in reading the book the fans used their imagination - including default notions of ethnicity - to see Rue as White. That is, young readers inured to definitions of African Americans as "perpetrators" whitewashed Rue's "innocent" character to align with learned conventions in media. Thus, there was no race controversy until they learned of their categorical error while watching the film: the "victim" they had imagined as White was instead Black. Instead of accepting this new association, the young fans who wrote the tweets expressed an unwillingness to define Rue in any way except as an "Other," reflecting deep-seated prejudices stemming from historically-reiterated representations of race.

\section{Discussion}

Kellner contends that "popular media texts... articulate specific ideological positions and help reproduce dominant forms of social power" (4). American youth saturated in media culture are continuously exposed to recurring stereotyping and/or exclusion of people of color as they begin to understand the world and the people in it. Thornton notes that the "dominant framework of Whiteness" presented by the media "is both a set of cultural practices and a vantage point from which individuals understand their social worlds and their own identities and experiences" (426), recognizing the crucial relationship between text and subject. Echoing this recognition, Storey suggests that ideology is not only created by "the makers of the image, but activated from an already existing cultural repertoire... Which codes are mobilized will largely depend on the triple context of the location of the text, the historical moment and the cultural formation of the 
reader" (123). Storey identifies a key relationship between media producers and their audience at a particular cultural moment that can be applied to this research. Young Americans receive mixed messages about race in a consumer society determined to define itself as "postracial": on one hand, political figures, educators, and community leaders espouse egalitarianism and tolerance; at the same time, media producers who have youth's attention "hail" them with a juggernaut of stereotypes, exclusion, and marginalization of people of color.

Perhaps it is no surprise that the angry Hunger Games fans internalized the codes presented to them by commercial media culture about race: the constant positioning of audiences within a White, corporate-driven media culture can be put forth as a compelling explanation for the fans' reluctance to see Black characters as worthy of respect, love, and empathy in the same way White characters are. The negative and limited portrayals in Hollywood film, primetime TV, commercial news, advertising, and music are crucial to understand how many young Hunger Games fans conveyed not only reluctance to feel empathy for Black characters but also outright hostility. In myriad ways, the commodity form provides "an affirmation rather than negation of the established order" (Marcuse 59) in mediated representations of race, providing a clear reason (not a justification) as to why some Hunger Games fans responded with vitriol when invited to feel empathy for an African American. The tweeting controversy provides support for Morgan's assertion that "hard-line condemnation of entire groups of people seems to be based less on our actual relationship with those people than on our relationship with media," a finding that speaks directly to the relationship between representations of people of color in commercial media and perceptions about basic human worth.

\section{Conclusion}

As Holmes observes, the "Hunger Games Tweets... illuminated long-standing racial biases 
and anxieties. The a-hundred-and-forty-character-long outbursts were microcosms of the ways in which the humanity of minorities is often denied and thwarted, and they underscored how infuriatingly conditional empathy can be." Unfortunately, the racist tweets are not an isolated occurrence. In 2011, young Black actor Donald Glover auditioned to star in The Amazing Spiderman. He did not get the role (given instead to a White actor), but did receive death threats (Stewart). This research could have focused on that case, involving the connection commercial media texts make between Whiteness and American identity. The Hunger Games incident similarly underscores the importance of considering interconnections between mediated race representations, political economy, and conceptions of "color blind" American society. Focusing on this relationship aids in understanding how youth growing up in a multicultural U.S. develop notions of who is inherently desirable, lovable, and worthy of empathy and respect.

Although most of the young tweeters were White Americans, it is important to note that Hunger Games was not solely intended for - neither was it only seen by - a U.S. audience. In September 2012, Lions Gate announced agreements with Spain and Germany to distribute the Hunger Games series, with similar agreements planned with Australia, Latin America, Russia, Poland and Korea (McNary). Globalization - and its concomitant interconnectedness encourages broader discussions about the relationship between commercial texts, ideological representations, and media consumers. Although it is beyond the intended scope of this study, the transnational reach of a U.S. media product like Hunger Games necessitates recognition of a global media audience, and future conversations about mediated race representations should be expanded to examine the unidirectional export of racial ideologies on a global scale. 


\section{Works Cited}

Abraham, Linus. "Media Stereotypes of African Americans." Images that Injure: Pictoral Stereotypes in the Media. Ed. Paul Martin Lester and Susan Dente Ross. Westport: Greenwood Publishing Group, 2003. 87-92. Print.

Alexander, Bryan. “'Hunger Games' Fans Split Hairs Over Blond Star Lawrence.” USA TODAY. USA TODAY. 26 Mar. 2012. Web. 11 Sept. 2012.

Althusser, Louis. "Ideology in Ideological State Apparatuses." Cultural Theory and Popular Culture: A Reader, $3^{\text {rd }}$ edition. Ed.John Storey. London: Pearson Publishers, 2009: 302-312. Althusser, Louis, and Etienne Balibar. Reading Capital. Trans. Brewster, Ben. Brooklyn: Verso Books, 2009. Print.

Anderson, L.V. "Talking to Teens Who Tweeted Racist Things About 'The Hunger Games'.” Brow Beat: Slate's Culture Blog. Slate. 11 Apr. 2012. Web. 11 Sept. 2012.

Andrews, David L. “The Fact(s) of Michael Jordan's Blackness: Excavating a Floating Racial Signifier," Sociology of Sport 13 (1996): 125-58. Print.

Beeby, Dean. "Bank of Canada Bans Image of Asian Woman From \$100 Bill." Financial Post. Canadian Press. 17 Aug. 2012. Web. 11 Sept. 2012.

Bernardi, Daniel. "Introduction: Race and the Hollywood Style." Classic Hollywood, Classic Whiteness. Ed. Daniel Bernardi. Minneapolis: University of Minnesota Press, 2001: xiii-xxvi.

---. The Birth of Whiteness: Race and the Emergence of United States Cinema. New Brunswick, NJ: Rutgers University Press, 1996. Print.

Dowe, Peark K. Ford. "Racial Attitudes in America: Post-Racial In The Age Of Obama Fails To Exist.” Blair-Rockefeller Poll. University of Arkansas, n.d. Web. 11 Sept. 2012.

Bogle, Donald. Toms, Coons, Mulattoes, Mammies, and Bucks: An Interpretive History of Blacks in American Films. New York: Continuum, $4^{\text {th }}$ edition, 2001. Print. 
Bowles, Scott. “'Hunger Games' and ‘Twilight' Stoke Passions Among Fans.” USA TODAY. USA TODAY, 28 Mar. 2012. Web. 11 Sept. 2012.

Byrne, Bridget. "Post-Race? Nation, Inheritance and the Contradictory Performativity of Race in Barack Obama's 'A More Perfect Union' Speech,” Thirdspace: A Journal of Feminist Theory \& Culture. 10.1 (2011): n. pag. Web. 11 Sept. 2012.

Coleman, Robin R. Means. "Black Sitcom Portrayals.” Gender, Race, and Class in Media: A Text-Reader. Ed. Gail Dines and Jean M. Humez. Thousand Oaks: Sage Publications, 2000. 79-88. Print.

Corley, Charles. "The Media: Crime Rates and Race." Race, Crime, and the Media. Ed. Robert L. Bing. New York: McGraw-Hill, 2010: 45-54. Print.

Dixon, Travis L. and Christina L. Axocar. "Priming Crime and Activating Blackness: Understanding the Psychological Impact of the Overrepresentation of Blacks as Lawbreakers on Television News.” Journal of Communication 57.1 (2007): 229-53. Print.

De Oca, Jeffrey Montez. "White Domestic Goddess On a Postmodern Plantation: Charity and Commodity Racism in 'The Blind Side'.” Sociology of Sport 29 (2012): 131-50. Print.

Dubrofsky, Rachel E. “The Bachelor: Whiteness in the Harem.” Critical Studies in Media Communication 23.1 (2006): 39-56. Print.

Entman, Robert M. and Andrew Rojecki. The Black Image in the White Mind: Media and Race in America. Chicago: The University of Chicago Press, 2000. Print.

Gabriel, John. Whitewash: Racialized Politics and the Media. NewYork: Routledge, 1998. Print. Gilliam, Franklin D., Jr., Shanto Iyengar, A. Simon and O. Wright. "Crime in Black and White: The Violent, Scary World of Local News." Harvard International Journal of Press/Politics 1 (1996): 6-23. Print. 
Goodykoontz, Bill. "Despite Oscar Notice, Black Actors Still Hit Limits in Film.” USA TODAY. USA TODAY, 24 Feb. 2012. Web. 11 Sept. 2012.

Goslett, Miles. "Race Row as Black Stars Are Airbrushed From Couples Retreat Film Poster." Mail Online. The Daily Mail, 15 Nov. 2009. Web. 29 Aug. 2012.

Hall, Stuart. "The White of Their Eyes: Racist Ideologies and the Media." Gender, Race, and Class in the Media: A Text-Reader. Ed. Dines, Gail and Jean M. Humez. Thousand Oaks: Sage Publications, 2000. 89-93. Print.

---. "The Spectacle of the 'Other'”. Representation: Cultural Representations and Signifying Practices. Ed. Hall, Stuart. Thousand Oaks: Sage Publication, 1997. 223-90. Print. Henderson, Carol E. “'King Kong Ain’t Got Sh** On Me’: Allegories, Anxieties, and the Performance of Race in Mass Media.” Journal of Popular Culture 43.6 (2010): 1207-21. Holmes, Anna. "White Until Proven Black: Imagining Race in Hunger Games.” The New Yorker. The New Yorker, 30 Mar., 2012. Web. 11 Sept. 2012. hooks, bell "Eating the Other: Desire and Resistance." The New Consumer Society Reader. Ed. Schor, Juliet and Douglas B. Holt. New York: The New Press, 2000. 343. Print.

Isaksen, Judy. “Resistive Radio: African Americans' Evolving Portrayal and Participation from Broadcasting to Narrowcasting.” Journal of Popular Culture 45.4 (2012): 749-68. Print.

Jackson, Ronald L. II. Scripting the Black Masculine Body: Identity, Discourse, and Racial Politics in Popular Media. Albany: State University of New York Press, 2006. Print. Jurgensen, John. "How Technology, Teen Franchises and Marketing Hype are Transforming Hollywood's Casting Calls: Auditions Via Skype.” The Wall Street Journal. The Wall Street Journal, 25 Feb. 2012. Web. 11 Sept. 2012.

Kaplan, Roy. The Myth of Postracial America: Searching for Equality in the Age of Materialism. 
Lanham: R\&L Education, 2011. Print.

Kellner, Douglas. Media Culture: Cultural Studies, Identity and Politics Between the Modern and the Postmodern. New York: Routledge, 1995. Print.

Kern-Foxworth, Marilyn. Aunt Jemima, Uncle Ben, and Rastus: Blacks in Advertising, Yesterday, Today, and Tomorrow. Westport: Greenwood Press, 1994. Print.

Ladson-Billings, Gloria. “'Who You Callin' Nappy-Headed?' A Critical Race Theory Look at the Construction of Black Women." Race, Ethnicity and Education 12 (2009): 87-99. Print.

Marcuse, Herbert. One-Dimensional Man: Studies in the Ideology of Advanced Industrial Society. Boston: Beacon Press, 1964. Print.

Mastro, Dana and Bradley Greenberg. "The Portrayal of Racial Minorities on Prime Time Television." Journal of Broadcasting and Electronic Media: 4 (2000): 690-730. Print.

McChesney, Robert. Interview Behind the Screens: Hollywood Goes Hypercommercial. Media Education Foundation. Prod. Sut Jhally, 2008. DVD.

McElroy, Molly. "Unconscious Racial Attitudes Playing Large Role in 2012 Presidential Vote.” UW Today. University of Washington 7 May 2012. Web. 11 Sept. 2012.

McNary, Dave. "Lionsgate, Alliance ink output deal for Spain." Variety Magazine. 11 Sept 2012. Web. 12 Sept 2012.

Mendible, Myra. "Humiliation, Subjectivity, and Reality TV. Feminist Media Studies. 4 (2004): 335-338. Print.

Morgan, Michael. The Mean World Syndrome. Media Education Foundation. Prod. Sut Jhally, 2010. DVD.

Romano, Andrew, Aku Ammah-Tagoe, and Brian No. "Black in the Age of Obama." Newsweek 153.17 (2009): 42-45. Print. 
Sanders, Meghan S. and Srividya Ramasubramanian. “An Examination of African Americans' Stereotyped Perceptions of Fictional Media Characters.” Howard Journal of Communications 23.1 (2012): 17-29. Print.

Snead, James. White Screens/Black Images: Hollywood from the Dark Side. New York: Routledge (1994). Print.

Stewart, Dodai. "Racist Hunger Games Fans are Very Disappointed.” Jezebel. 26 Mar., 2012. Web. 11 Sept. 2012.

Storey, John. Cultural Theory and Popular Culture: An Introduction. Athens: University of Georgia Press, 2012. Print.

Thornton, D. "Psych's Comedic Tale of Black-White Friendship and the Lighthearted Affect of 'Post-Race’ America.' Critical Studies in Media Communication 28: 424-449. Print.

Valby, Karen. “Team 'Hunger Games’ Talks: Author Suzanne Collins and Director Gary Ross on Their Allegiance to Each Other, and Their Actors.” EW.com. Entertainment Weekly, 7 Apr. 2011. Web. 11 Sept. 2012.

van Ginneken, Jaap. Screening Difference: How Hollywood's Blockbuster Films Imagine Race, Ethnicity, and Culture. Lanham: Rowman \& Littlefield Publishers, 2007. Print.

Weiss, Alexander and Steven Chermak. "The News Value of African American Victims: An Examination of the Media's Presentation of Homicide." Journal of Crime and Justice 21: 7188. Print.

Wenner, Jann. "Ready for the Fight: Rolling Stone Interview with Barack Obama." Rolling Stone Magazine. Rolling Stone Magazine, 10 May 2012. Web. 11 Sept. 2012.

Wise, Tim. Colorblind: The Rise of Postracial Politics and the Retreat from Racial Equality. San Francisco: City Lights Publisher, 2010. Print. 